\title{
Dutch Liberation Festivals: A Vehicle to More Politically Active Young Citizens, or Merely the Same Selective Audience?
}

\author{
Manja Coopmans ${ }^{1,2}$ (D)
}

Accepted: 17 May 2018 / Published online: 24 May 2018

(C) The Author(s) 2018

\begin{abstract}
This article follows up on claims made on the motivating role of national commemorations for young people's political participation. Cross-sectional data from a Dutch adolescent panel are utilised to focus on a commemoration activity popular amongst young people in the Netherlands, and empirically test to what extent participation in Dutch Liberation festivals amongst young adults (aged 19-20 years old) is associated with their inclinations to vote. To examine whether the association is spurious, several factors previously identified as important determinants of young citizens' broader civic engagement are accounted for, including parental communication about civic issues, citizenship activities offered at school, involvement in voluntary organisations, and various sociodemographic characteristics. Although the relationship between Liberation festival attendance and voting intentions is partially explained by a more general civic socialisation process, as indicated by, amongst others, the role of parental civic communication and voluntary work, the results show that Dutch Liberation festivals are positively associated with young people's voting intentions. Moreover, individuals with different educational trajectories or socioeconomic backgrounds have similar chances of attending the Liberation festivals, highlighting the potential of Dutch Liberation festivals to promote political participation amongst all young people equally. At the same time, Liberation festivals are less often attended by youth identifying with a non-Dutch ethnic background, thereby risking reinforcing gaps in political engagement between youth with and without a migration background.
\end{abstract}

Keywords Political engagement · Commemoration · Dutch liberation festivals · Socialisation · Voting $\cdot$ Youth

Manja Coopmans

M.Coopmans@uva.nl

1 Department of Child Development and Education, University of Amsterdam, Postbus 15776, 1001 NG, Amsterdam, The Netherlands

2 Department of Sociology and ICS (Inter-University Centre for Social Science Theory and Methodology), Utrecht University, Utrecht, The Netherlands 


\section{Introduction}

Political participation is considered an important aspect of active citizenship and crucial for an effective democracy (Putnam 2000). According to Verba et al. (1995), political participation can be described as "voluntary activities by ordinary people directed towards influencing directly or indirectly political outcomes at various levels of the political system" (p. 38). Over the past few decades, an intense debate soared in both the United States and Europe regarding a potential decline in levels of political participation amongst young people - at least when looking at more traditional forms such as voting (Fieldhouse et al. 2007; Putnam 2000; Russo and Stattin 2017; Sloam 2014). The last parliamentary elections in the Netherlands in 2017, for instance, showed that despite a significant turnout $(81.9 \%)$, the percentage of young people who voted (i.e. those between 18 and 24 years old) dropped from 77\% in the 2012 parliamentary elections to 67\% in 2017 (NOS 2017), a decline of almost 125,000 young citizens. Amongst youngsters who (had) followed a vocational educational track (as compared to those in college or university education), turnout was even lower.

This falling voter turnout amongst young people is worrisome, as it means an unequal representation of young people's voices in politics, thereby threatening the democratic ideal of political equality, and potentially resulting in young people becoming even more marginalised from electoral politics. Moreover, the act of (not) voting is itself habit-forming (Coppock and Green 2016; Plutzer 2002), meaning that not voting at a young age decreases chances of voting in future elections. A prominent example of an attempt to counter the declining political participation amongst young citizens is the promoting of youth's involvement in civic (i.e. non-political) activities, for instance by organising extracurricular citizenship activities at school (Geboers et al. 2013), or by stimulating them to join voluntary organisations (McFarland and Thomas 2006). Recent studies, however, show that civic involvement is often highly segregated, with higher educated, politically engaged citizens more likely to join in civic activities (Sloam 2014; Van Ingen and Van der Meer 2016). The quality of citizenship education offered at school also varies substantially (Geboers et al. 2013; Manning and Edwards 2014), providing young people with unequal chances of developing into politically active citizens.

A potentially interesting alternative are Dutch Liberation festivals, organised annually on 5 May to commemorate the end of the Second World War in 1945, and the enduring freedom in the Netherlands since. Although Dutch Liberation festivals are most popular for the musical performances of famous artists, they are also meant to raise awareness of core democratic rights and values such as freedom, tolerance, and respect. Dutch Liberation festivals are but one example of the many activities that are annually organised around the world to commemorate the Second World War (Liu et al. 2005; McCrone and McPherson 2009). During the past decade, the discussion on whether the national past and the associated (institutionalised) rituals to commemorate this past - that is, national commemorations-are able to promote (democratic) citizenship values and behaviours, and political participation in particular, has resurfaced (Elgenius 2011; Haskins 2015; Liu and Hilton 2005). Building on Durkheim's (1912-1995) assumption that rituals have the ability to reinforce shared beliefs within a society, several reports-especially in the educational sector-have connected commemoration of a national past to political engagement amongst young citizens (Cowan et al. 2014; Van Nieuwenhuyse and Wils 2012). Empirical research on the relationship between young citizens' commemorative and political participation is, however, scarce. 
The combination of popular culture and content gives informal commemorations such as Dutch Liberation festivals the potential to promote more political awareness amongst all youth equally. Whereas more formal commemorations have been argued to be mainly attended by an elite audience (Fox 2014), this is different for more informal commemorative activities. The Liberation festivals are free of charge and organised in 14 different cities across the country, thereby creating opportunities to reach a large segment of the population. Annually, around one million citizens visit one of the 14 festivals, of which $50 \%$ is under the age of 25 (De Regt and Van der Lippe 2017). At the same time, the fact that the festivals are most known for their music and take place only once a year makes it questionable to what extent they can impact people's behaviours. An alternative explanation of positive associations between young people's festival attendance and their political participation is therefore that both commemorative and political participation are outcomes of a more general civic socialisation process (including both non-political and political socialisation), and we are, in fact, looking at a spurious association.

Utilising data from a representative sample of Dutch young adults (aged 19-20 years old) from the Children of Immigrants Longitudinal Survey in the Netherlands (CILSNL), the present study contributes to the existing literature by examining the extent to which their participation in Dutch Liberation festivals positively influences their inclination to vote. Structural equation modelling is applied to test the relationship between young adults' festival attendance and voting intentions whilst simultaneously including a number of factors that have traditionally been considered important determinants of young adults' broader civic engagement (Amnå 2012; Verba et al. 1995), including parental communication about civic issues, citizenship activities offered at school, involvement in voluntary organisations, and various sociodemographic characteristics. In doing so, this study is one of the first to structurally test whether (informal) national commemorations have the potential to promote young adults' political participation, or whether we are merely looking at the same 'selective' audience.

\section{Theory}

\subsection{National Commemorations and Young Adults' Political Participation}

National commemorations are institutionalised rituals organised on designated dates on which a nation commemorates a defining event in its history as a nation (Schwartz 2015). According to Renan (1882-1990), the commemoration of a national trauma imposes a sense of duty on citizens by staging experiences that emphasise the importance of common efforts to avoid repeating history. As such, national war commemorations have been argued to work as civic lessons through which people come to accept and internalise societal norms, values, and responsibilities (Haskins 2015). This usage of commemorations as 'lessons from the past' is also visible in many European war commemorations, Dutch Liberation festivals included, that use memories of the Second World War to focus on democratic values such as freedom, equality, and justice (Liu et al. 2005). At every Dutch Liberation festival, for instance, a 'Square of Freedom' is present, where non-governmental organisations share stories of the past, such as the Netherlands Veterans Institute, and inform visitors of current issues relating to the fragility of freedom in the Netherlands and abroad, such as Amnesty International, the Red Cross, and ProDemos. During the many musical performances, attention is also paid to past and present wars, for instance by the 
'Ambassadors of Freedom', who travel across the country to perform at several Liberation festivals.

In addition to functioning as a 'lesson from the past', it has been argued that commemorative rituals remind citizens of why they belong together by producing a momentarily shared experience amongst its participants, heightening what Durkheim (1912-1995) referred to as 'collective effervescence'. Supposedly, the temporary sense of collective consciousness that follows from participating in commemorative rituals not only carries over into more persistent feelings, but also increases an urge to act and contribute to the group's - or in this case society's - well-being (see Collins 2004 for a review). Dutch Liberation festivals try to accomplish a feeling of shared belonging during the 'Five to Five moment', in which visitors of all 14 festivals are invited to dance simultaneously to the same song and 'pass along the freedom', which is symbolised by large balloons that are let loose over the audience. The 'Fire of Liberation' that is carried across the country and burns at all festivals is another reference to a shared national past.

The combination of a heightened sense of duty and increased awareness of democratic values and the importance of a democratic system, which supposedly follow from attending a Dutch Liberation festival, increase one's chances of translating the above described urge to act, which is also supposed to follow from participating in commemorative rituals, into concrete actions to contribute to the continuance of democracy, of which political participation is considered a key aspect (Putnam 2000). This reasoning is consistent with behavioural theories such as Ajzen's (1991) theory of planned behaviour. Obviously, many forms of political participation exist. One of the most visible forms that adolescents grow up with in a democracy, however, is voting in local, national, and international elections. In the Netherlands, for instance, municipality and parliamentary elections are held every 4 years, and elections for the European parliament every 5 years. Voting is also one of the least demanding forms of political participation compared to, for instance, working for a political campaign or participating in a political protest (Verba et al. 1995), and therefore a logical first step for young people in the process of political participation. We therefore hypothesise that: Young people who have attended a Dutch Liberation festival are more inclined to vote (H1).

\subsection{Alternative Explanations of Associations Between Commemorative and Political Participation}

An alternative explanation of positive associations between young people's Liberation festival attendance and their inclinations to vote is that the association is caused by other factors predicting both commemorative and political participation, that is, a spurious relationship. In this study, we distinguish between two types of alternative explanations. First, we are interested in the extent to which commemorative and political activities are outcomes of a more general civic socialisation process. In this case, commemorative and political participation are both considered expressions of a certain level of civic engagement, a term used to describe a wide range of citizenship attitudes and behaviours, including, but not limited to, participation in political, social, and even cultural activities (Adler and Goggin 2005; Amnå 2012). We look at three environments that are thought to be crucial for young people's civic socialisation: the home, the school, and the out-of-school (i.e. leisure time) environment. In all three cases, we focus on socialisation forms that directly address civic issues: by communicating with one's parents about social or political issues, via citizenship education at school, or through involvement in voluntary organisations. Second, 
to examine selection processes as an alternative explanation of associations between commemorative and political participation, we consider several sociodemographic characteristics that previous studies have shown to be particularly relevant in predicting levels of civic engagement, including, amongst others, educational trajectory, socioeconomic status, and ethnic origin (Verba et al. 1995).

\subsubsection{The Home Environment: Parental Civic Communication}

Traditional socialisation theories often consider the family-and the primary caregivers, most often the parents, in particular - as the most likely agents of socialisation during adolescence (Glass et al. 1986; Parsons and Bales 1956). Literature focusing more specifically on civic participation has also highlighted the crucial role of parents' civic orientations in their children's civic socialisation process (Beck and Jennings 1982; Verba and Nie 1972). Following up on this, numerous studies have shown that parents exert a substantial influence on the civic attitudes and behaviours of their children, especially during childhood and adolescence (Hooghe and Boonen 2015; Jaspers et al. 2008). One way in which this learning process may commence is through communication. Talking about civic issues or events in everyday life not only teaches children about important societal topics, but also clarifies their parents' values and beliefs, which increases the likelihood of children adopting similar attitudes and behaviours (Jennings et al. 2009; Quintelier 2015b).

Moreover, it creates an environment in which children are actively familiarised with a civic engagement, including, as discussed, not only political attitudes and behaviours, but also social and cultural ones. Schmid (2012), for instance, found that, in family environments in which discussions about civic issues were more frequent, adolescents were also more aware of what it meant to act in a socially responsible way, a concept closely related to one of the key aspects of civic engagement, namely the willingness to be committed to the well-being of a larger group (Sherrod et al. 2002). Talking about civic topics with one's parents can thus be expected to heighten levels of civic engagement, thereby increasing chances of participating in activities expressing this engagement, for instance through voting, but also through participation in nationally organised commemorations. We therefore hypothesise that: The association between young people's previous Liberation festival attendance and their inclination to vote is partially explained by parental civic communication (H2).

\subsubsection{The School Environment: Extra-Curricular Citizenship Activities}

Another important socialising agent facilitating the civic socialisation process of young citizens is the school. Not only does general education aid the development of basic knowledge and skills necessary for civic engagement (Verba et al. 1995), citizenship has, since the 1990s, been introduced as a compulsory school subject in almost all European countries, the Netherlands included (Eurydice 2012). One of the main goals of citizenship education in the Netherlands is to foster active citizenship amongst young people, which includes, amongst others, active political participation, but also being able to fulfil social, everyday life tasks that are part of being a citizen, such as acting in a socially responsible manner, and commitment to manifestations of Dutch culture (Ten Dam et al. 2011; Ten Dam and Volman 2007). It is, however, left to schools to decide to what extent and in what way they want to accomplish this. Hence, young people's citizenship outcomes can be 
expected to differ depending upon the emphasis that is placed upon citizenship education by the school the student attends.

Although empirical research on the effects of citizenship education on young people's civic engagement has provided mixed evidence, extra-curricular citizenship activities (i.e. additional student activities supervised by the school to help foster active citizenship amongst their students), such as voluntary service activities or a visit to parliament, seem promising, at least where the political aspect of citizenship behaviour is concerned (Geboers et al. 2013). This form of 'learning by doing' offers students active, participative experiences that help them acquire both a more realistic picture of what civic engagement looks like, as well as an opportunity to practise specific skills that will help them develop into civically active citizens. Supporting this line of argumentation, students participating in extra-curricular citizenship activities such as a school council or a visit to parliament or a museum have been found to be more interested in civic affairs and social problems, as well as being more politically active later in life (Geboers et al. 2013; Hoskins et al. 2012; Keating and Janmaat 2016). Following this line of argumentation, young people who attended a school that paid more attention to citizenship education in the form of extra-curricular citizenship activities can be expected to develop into more actively participating citizens, both in terms of commemorative and political participation. Hence, we hypothesise that: The association between young people's previous Liberation festival attendance and their inclination to vote is partially explained by the extra-curricular citizenship activities offered at $\operatorname{school}(\mathrm{H} 3)$.

\subsubsection{The Out-of-School Environment: Involvement in Voluntary Organisations}

Extra-curricular activities outside school (i.e. organised by other institutions) have also been shown to promote political participation amongst adolescents, a common example being involvement in voluntary organisations (Marzana et al. 2012; McFarland and Thomas 2006; Quintelier 2008, 2015a). Voluntary organizations are argued to be powerful political socialisation agents engaging young people in politics through various mechanisms. In addition to the advantages of extra-curricular activities for young people's political participation that were described in the previous section, voluntary organisations also promote a sense of community and institutional trust which, according to theories on social participation (Cassel 1999; Olsen 1972), motivate people to participate in other civic and political activities (Cicognani et al. 2012). A third argument often used to underline the political or civic value of voluntary organisations is that of relational support, referring to the facilitating (or: recruiting) role of relationships with other members of the organisation (McFarland and Thomas 2006; Sidney Verba et al. 1995). Based upon these arguments, volunteering can be expected to show positive associations with both festival attendance and voting intentions (many Liberation festivals are even partially run by volunteers). We therefore hypothesize that: The association between young people's festival attendance and their inclination to vote is partially explained by their involvement in voluntary organisations (H4).

\subsubsection{Sociodemographic Factors}

In addition to the forms of civic socialisation discussed above, previous research on civic participation has identified several sociodemographic characteristics that determine levels of civic engagement in general and electoral participation in particular. Building on 
Bourdieu's theory of social and cultural reproduction (Bourdieu 1984; Bourdieu and Passeron 1977), studies have shown that young people from families with more resources have higher chances of becoming politically active citizens (McFarland and Thomas 2006; Sloam 2014). Two of the most consistent resources are socioeconomic status and level of education (Bovens and Wille 2010; Verba et al. 1995). A higher educational level and socioeconomic status have also been found to positively predict various forms of commemorative participation (Lubbers and Meuleman 2016). In addition to economic resources, Bourdieu mentions the importance of cultural resources, of which highbrow activities such as reading literature and visiting museums are prominent examples (De Graaf et al. 2000). Such activities can be expected to not only signal but also intensify one's civic engagement, including - as discussed before-political attitudes and behaviours, as well as an interest in the national past and its commemorations (see, for instance, Cowan and Maitles 2011; Savenije and De Bruijn 2017). Hence, we expect that: The association between young people's previous Liberation festival attendance and their inclination to vote is partially explained by their level of education ( $\mathrm{H} 5 \mathrm{a})$, the socioeconomic status of their parents $(\mathrm{H} 5 \mathrm{~b})$, their reading activities $(\mathrm{H} 5 \mathrm{c})$, and their museum activities (H5d).

Another demographic characteristic we believe to be relevant when examining relationships between commemorative and political participation is migration background. Previous studies have shown lower levels of political engagement amongst citizens with a migration background, often explained by lower levels of socio-cultural integration, socioeconomic status, and feelings of identification with the politics of the country of origin (De Rooij 2012; Sanders et al. 2014; White et al. 2008). Differences in voting behaviours are less apparent for children of immigrants (Humphries et al. 2013; Quintelier 2009). Levels of commemorative participation are also lower amongst citizens with a (non-Western) migration background (Coopmans et al. 2016). This is not surprising: Second World War commemorations in Europe are often focused on the history of the native population, as large-scale immigration did not start until after the war (Messina 2007). For young people born in the Netherlands, the extent to which their migration background impacts their participation can be expected to depend on their identification with their ethnic origin, as well as their identification with the Netherlands (see also Coopmans et al. 2015). We therefore hypothesise that: The association between young people's previous Liberation festival attendance and their inclination to vote is partially explained by their ethnic (H6a) and national identification (H6b).

\section{Methods}

\subsection{Data}

We make use of the fifth wave of the 'Children of Immigrants Longitudinal Survey in the Netherlands' (CILSNL), which is a continuation of the Dutch part of the 'Children of Immigrants Longitudinal Survey in Four European Countries' (CILS4EU). The panel study describes the life courses of adolescents of native and immigrant descent in the Netherlands. The first wave was collected in 2010 amongst 14-year-old adolescents in their third grade of secondary school. A three-stage stratified sample design was applied, with an oversampling of schools with a high share of students of non-Western origin. The initial response rate amongst schools in the Netherlands was 34.9\%. To increase this participation rate, schools that refused were replaced with schools highly similar to the initially sampled 
schools, leading to a school-level participation rate of $91.7 \%$, with a class-level participation rate of $94.5 \%$ and a student-level participation rate of $91.1 \%$. In total, 4963 pupils in 252 classes in 118 schools participated in the first wave, including a subset of 600 students who were not part of the original sampling frame (for more information on sampling design and response rates, see CILS4EU 2016). As changes in class composition between the third and fourth year of secondary school are common in the Netherlands, in the second wave, schools were asked to participate with all fourth-grade classes that held initial first wave respondents. Consequently, 2118 additional students were interviewed. In subsequent waves, all 7081 respondents were approached.

Information on our main variables of interest, commemorative and political participation, was collected in the fifth wave of CILSNL in 2015 (Jaspers and van Tubergen 2015). ${ }^{1}$ In this wave, all respondents were at least 18 years old, and thus allowed to vote. In total, 3836 respondents participated in wave 5. To overcome power issues and ensure a large enough sample size, we initially kept all (trustworthy) respondents who completed the full version of the questionnaire, which included items on commemorative and political participation $(N=3761){ }^{2}$ Information on citizenship activities offered at the participating schools during the time respondents were still in school (i.e. wave 1-2) was collected in 2016 in the CILSNL Citizenship Education project (Coopmans 2016). To merge the school-data with the individual-level data, information from the earlier waves was used. Information on citizenship activities organised at school was available for 1935 respondents. Respondents with missing values on our variables of interest were excluded. Most missing values were found for parental civic communication $(N=235)$ and parental socioeconomic status $(N=224)$. In total, 1512 respondents had valid information on all variables of interest, originally sampled from 58 different schools. Although a drastically smaller sample size than our initial sample, this is the first dataset that allows for the testing of associations between young adults' commemorative and political participation, whilst considering potentially confounding factors at the individual and school level.

\subsection{Measures}

Voting intentions our dependent variable, was measured by asking respondents in wave 5: "If parliamentary elections were held today, for which party would you vote?" Answer categories comprised all major parties in the Netherlands, as well as the options 'other party', 'I don't know', 'blank', and 'I would not vote'. A dichotomous variable was created, distinguishing between people who indicated that they would not vote, and people who intended to vote, including those voting 'blank'. Since we do not know whether respondents who responded with 'I don't know' were unsure of whether they would vote or of which party

\footnotetext{
1 Since this topic was only covered in wave 5, we were unable to analyse changes in commemorative and political participation. The panel structure was, however, valuable in that it allowed us to examine relationships between previous socialising environments (i.e. in wave 1-2) and civic engagement several years later (i.e. wave 5). For the construction of educational track, parental socioeconomic status, and parental civic communication, data from the first four waves was used as well (Jaspers and van Tubergen 2014; Kalter et al. 2016a, b, c). For a more extensive overview of which wave was used for which measurement, see Table 3 in the "Appendix".

${ }^{2}$ In total, 72 respondents completed a shortened version of the questionnaire. Moreover, three respondents were excluded because of untrustworthy answers.
} 
they would vote for (i.e. if they would fall in the category voters or non-voters), they were coded as missing and excluded from our analyses $(N=364){ }^{3}$

Participation in Dutch Liberation festivals was measured by asking respondents in wave 5 how often in the past years they had visited a Liberation festival on 5 May. Response categories were: (0) 'never'; (1) 'sometimes'; (2) 'almost always'. As we are more interested in factors predicting whether young adults attend at all than we are in factors that predict whether adolescents attend every year versus only once or twice, a dichotomous variable was created, distinguishing between respondents who had never attended a Liberation festival versus respondents who had either sometimes or almost always attended a Liberation festival.

Parental civic communication was measured using information from wave 2, thereby providing an indication of the civic home environment when respondents, who at the time of the interview were between 16 and 17 years old, still lived at home. Respondents were asked: "How often do your parents talk with you about political and social topics?" Response categories were: (0) 'every day'; (1) 'at least once a week'; (2) 'at least once a month'; (3) 'less often'; (4) 'never'. Response categories were recoded so that higher values indicated more frequent communication.

Extra-curricular citizenship activities offered at school were measured at the schoollevel. In an additional data collection, schools were asked whether they had organised the following extra-curricular citizenship activities in the school year 2010/2011 (the year in which the first data were collected) for the students who participated in the CILSNL data collection, i.e. wave 1): (a) elections; (b) debates; (c) visit to parliament; (d) other democracy related excursions or museum visits; (e) a democracy related guest lecture; (f) an extra exam course on social sciences; (g) student council. A distinction was made between activities that took place outside the school environment (i.e. visits to parliament and other excursions) and activities that took place inside the school environment (i.e. elections, debates, and guest lectures). The extra social sciences course and student council were included as separate items. Together, these four variables provided an indication of the civic school environment when respondents still attended (secondary) school.

Voluntary work was measured by asking respondents in wave 5: "In your spare time, how often do you do voluntary or community work?". Answer categories were: (0) 'every day'; (1) 'at least once a week'; (2) 'at least once a month'; (3) 'less often'; (4) 'never'. Response categories were recoded so that higher values indicated more frequent volunteering. A categorical variable was constructed, distinguishing between those volunteering structurally (i.e. at least once a month), those volunteering occasionally (i.e. less often than once a month), and those volunteering never. The latter acted as the reference category.

Educational trajectory was operationalised as the last known level of education, measured with the question "What is, at this moment, your most important activity?" Response categories were: (a) 'secondary school'; (b) 'intermediate vocational education'; (c) 'higher vocational or college education'; (d) 'university'; (e) 'working'; (f) 'unemployed'; (g) 'something else'. For those respondents answering (e), (f), or (g), we used information from earlier waves to construct their latest known educational trajectory (see Appendix Table 3). We distinguished between three tracks: (0) vocational (preparatory/intermediate vocational education); (1) college (higher general and college education); (2) university

\footnotetext{
3 Additional (multinomial logistic) analyses in which we did include respondents who did not yet know what to vote resulted in similar findings.
} 
(university preparatory education and university). Those in the vocational track acted as the reference category.

Parental socioeconomic status was taken into account using the International SocioEconomic Index of Occupational Status (ISEI) score of the mother or father of the respondent (Ganzeboom et al. 1992) as reported by the parents themselves in wave 1 and 2 . The highest score applied. If parental information was missing, parental occupation as reported by their children (i.e. the respondents) in wave 1 and 2 was used.

Reading activities was measured by asking respondents in wave 5 how often they read a book (not for school), and museum activities by asking how often respondents went to the museum. Answer categories for both questions were: (0) 'every day'; (1) 'at least once a week'; (2) 'at least once a month'; (3) 'less often'; (4) 'never'. Response categories were recoded so that higher values indicated more frequent reading or museum activities. Similar to our volunteering variable, two categorical variables were constructed, both distinguishing between structural, occasional, and never.

Ethnic identification was included by asking respondents in wave 5 to which non-Dutch group(s) they felt they belonged. Answer categories were: (0) 'no other group'; (1) 'Turkish'; (2) 'Kurdish'; (3) 'Moroccan'; (4) 'Berbers'; (5) 'Surinamese'; (6) 'Hindu'; (7) 'Creole'; (8) 'Javan’; (9) 'Chinese'; (10) ‘Curacao'; (11) 'Aruban’; (12) 'Antillean'; (13) 'Indonesian'; (14) 'other group'. A dummy variable was included distinguishing between those who did not identify with a non-Dutch group and those who did.

National identification was included by asking respondents in wave 5: "How strongly do you feel Dutch?". Answer categories were: (0) 'very strongly'; (1) 'fairly strongly'; (2) not very strongly; (3) not at all strongly'. Response categories were recoded so that higher values indicated higher levels of national identification. Due to the small number of respondents responding with 'not at all strongly', a categorical variable was constructed in which those identifying 'not very strongly' and 'not at all strongly' were combined in one group that acted as the reference category.

Controls To control for other sociodemographic factors, information was included on respondents' gender, whether respondents still lived with their parents, and the degree of urbanisation of the school location. Gender was operationalized as a dummy variable for male, living with parents as a dummy variable for respondents still living with their parents in wave 5, and urbanisation as the size of the municipality where the school was located that respondents attended in wave 1 (i.e. a continuous, school-level variable, indicating the number of citizens/10,000).

\subsection{Analytical Strategy}

Since we wanted to test a structural model in which festival attendance was both an independent variable predicting voting intentions, and a dependent variable predicted by civic socialisation measures and sociodemographic variables, generalised structural equation modelling was applied using Stata, version 15 (StataCorp 2017). Moreover, given that the data had a hierarchical structure (i.e. respondents within schools) and the models included not only individual characteristics but also school characteristics (i.e. citizenship activities offered at school), multilevel models were analysed. Finally, considering the dependent variables were dichotomous, logistic models were examined. Intercept-only models found an intraclass correlation of .129 for voting and .180 for festival attendance, meaning that 13 and $18 \%$ of the variation in voting intentions and festival attendance respectively can be attributed to the school that adolescents attended. As unobserved heterogeneity affects 
coefficients differently in logistic regressions than in linear regressions, it is difficult to interpret $(\log )$ odds ratios as substantive effects, or to compare them across models with different independent variables (Mood 2010). We therefore calculated and reported average marginal effects (AMEs), which are not only more easily interpretable in terms of substantive effect sizes than odds ratios, but also unaffected by unobserved heterogeneity that is unrelated to the independent variables in the models and therefore comparable across models. AMEs indicate the change in the probability of a respondent voting in the next elections (versus not voting) or having attended a Liberation festival (versus having never attended a Liberation festival), for every one-unit change in an explanatory variable, estimated over all the possible values of the variables in the model.

\section{Results}

\subsection{Descriptive Results}

Table 1 depicts descriptive information of our sample of 1148 young adults, the majority between 19 and 20 years old. The findings show that $87 \%$ intended to vote in the next elections, whilst $13 \%$ indicated not to want to vote. Taking the young adults who indicated to not yet know what political party they would vote for into account $(N=364)$, the statistics are comparable to the percentage of young people (i.e. below 24 years old) who voted in the last parliamentary elections in the Netherlands, namely 67\% (NOS 2017). About 60\% of our sample had visited a Dutch Liberation festival at least once over the past years.

On average, respondents had talked to their parents about political and social issues at least once a month. A little under half of the respondents was involved in voluntary organisations, either occasionally or structurally. Of the extra-curricular citizenship activities that could be offered at school during the school year 2010/2011, schools most often organized either a visit to parliament or other type of excursion (87\%), a student council (79\%), or an activity inside the school environment, such as a debate, mock elections, or a guest lecture (76\%). Around half of the schools offered an additional exam course in social sciences.

An examination of educational track indicated $43 \%$ had finished or was currently in the (preparatory) vocational track, whilst 57\% was in the (preparatory) college or university track. The former group is therefore somewhat under-represented compared to the general Dutch population between 15 and 25 years old with at least primary education (Statistics Netherlands 2016). Respondents' parents had, on average, an ISEI score of 44, which can be considered a medium socioeconomic status. Moreover, the majority of respondents read books in their leisure time (70\%), and a little over half of the respondents had visited a museum (57\%). Finally, $20 \%$ of the respondents identified with a non-Dutch ethnic group, and most identified fairly to very strongly with Dutch society.

\subsection{Explanatory Results}

Table 2 shows the AMEs of the multilevel logistic structural equation models estimating young adults' voting intentions and previous attendance at Dutch Liberation festivals. In Model 1, in which we included previous festival attendance as a potential predictor of future voting intentions (whilst controlling for gender, living with parents, and degree of urbanisation), we found a significant positive effect: Young adults who had visited a Liberation festival over the past years had a $7 \%$ higher chance of voting in the next elections 
Table 1 Descriptive statistics of the variables

\begin{tabular}{|c|c|c|c|c|}
\hline Variables & Min. & Max. & Mean & $\mathrm{SD}$ \\
\hline \multicolumn{5}{|l|}{ Individual-level $(N=1148)$} \\
\hline Voting intentions & 0 & 1 & .87 & \\
\hline Liberation festival attendance & 0 & 1 & .59 & \\
\hline Parental civic communication & 0 & 4 & 2.17 & 1.23 \\
\hline \multicolumn{5}{|l|}{ Voluntary work } \\
\hline Never & 0 & 1 & .54 & \\
\hline Occasionally & 0 & 1 & .30 & \\
\hline Structurally & 0 & 1 & .16 & \\
\hline \multicolumn{5}{|l|}{ Educational track } \\
\hline Vocational & 0 & 1 & .43 & \\
\hline College & 0 & 1 & .30 & \\
\hline University & 0 & 1 & .27 & \\
\hline Parental ISEI score & 0 & 88.96 & 43.97 & 19.94 \\
\hline \multicolumn{5}{|l|}{ Reading activities } \\
\hline Never & 0 & 1 & .30 & \\
\hline Occasionally & 0 & 1 & .36 & \\
\hline Structurally & 0 & 1 & .34 & \\
\hline \multicolumn{5}{|l|}{ Museum activities } \\
\hline Never & 0 & 1 & .43 & \\
\hline Occasionally & 0 & 1 & .50 & \\
\hline Structurally & 0 & 1 & .07 & \\
\hline Ethnic group identification & 0 & 1 & .20 & \\
\hline \multicolumn{5}{|l|}{ National identification } \\
\hline Not very strongly & 0 & 1 & .10 & \\
\hline Fairly strongly & 0 & 1 & .40 & \\
\hline Very strongly & 0 & 1 & .50 & \\
\hline Gender (male) & 0 & 1 & .42 & \\
\hline Living with parents & 0 & 1 & .74 & \\
\hline \multicolumn{5}{|l|}{ School-level $(N=57)$} \\
\hline Citizenship activities in school & 0 & 1 & .76 & \\
\hline Citizenship activities outside school & 0 & 1 & .87 & \\
\hline Extra social sciences course & 0 & 1 & .54 & \\
\hline Student council & 0 & 1 & .79 & \\
\hline Urbanisation & 1.18 & 77.36 & 14.70 & 2.18 \\
\hline
\end{tabular}

(versus not voting) compared to young adults who had never visited a festival, which is consistent with Hypothesis 1.

In Model 2, 3, and 4, we included three alternative explanations of associations between young adults' previous festival attendance and future voting intentions, all indicators of a more general civic socialisation process: the civic environment at home, measured by the frequency of civic communication with one's parents (Model 2), the civic environment at school, indicated by the extra-curricular citizenship activities offered (Model 3), and the civic environment out-of-school, measured by their involvement in voluntary organisations (Model 4). The inclusion of parental civic communication slightly decreased the AME of 


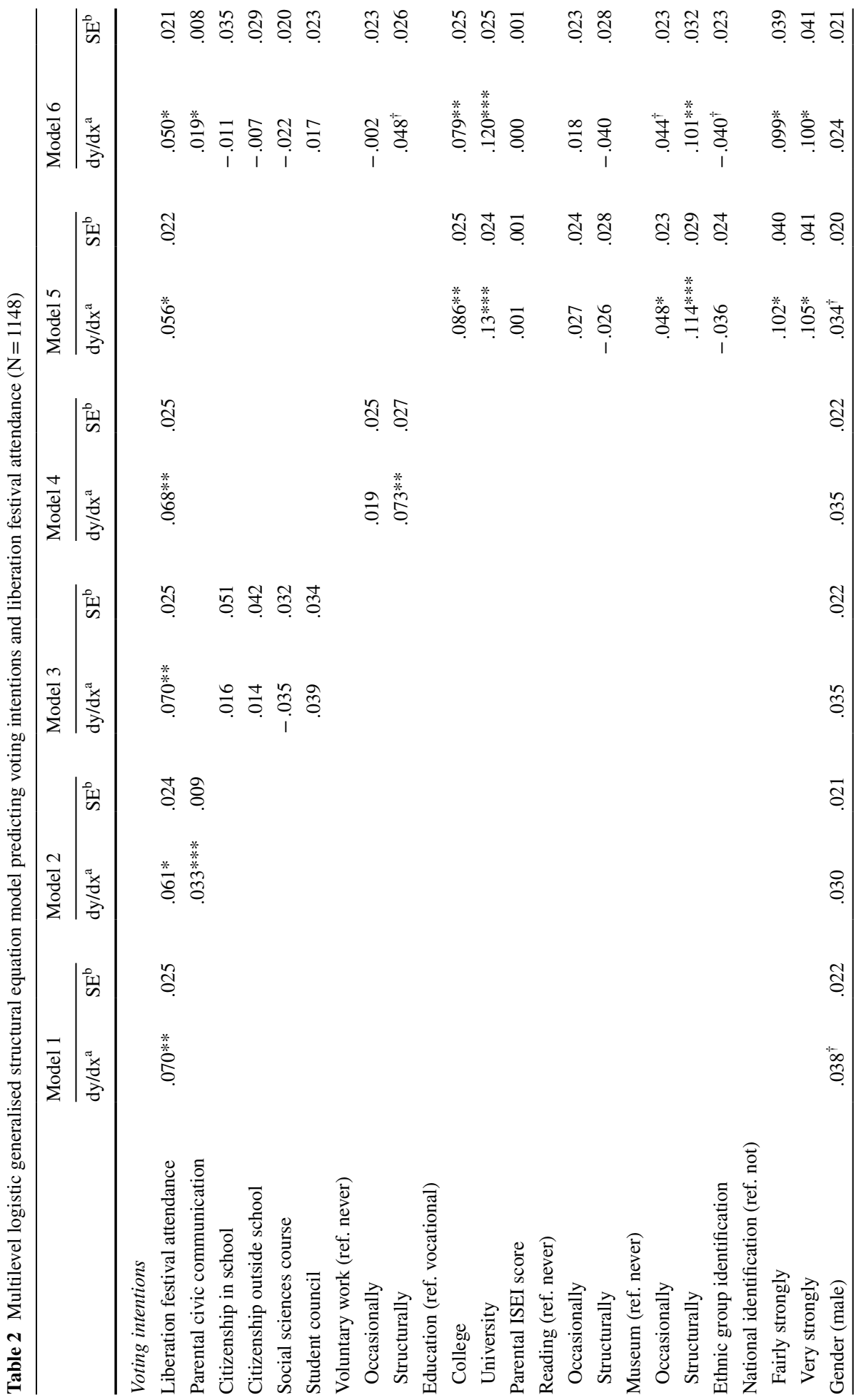




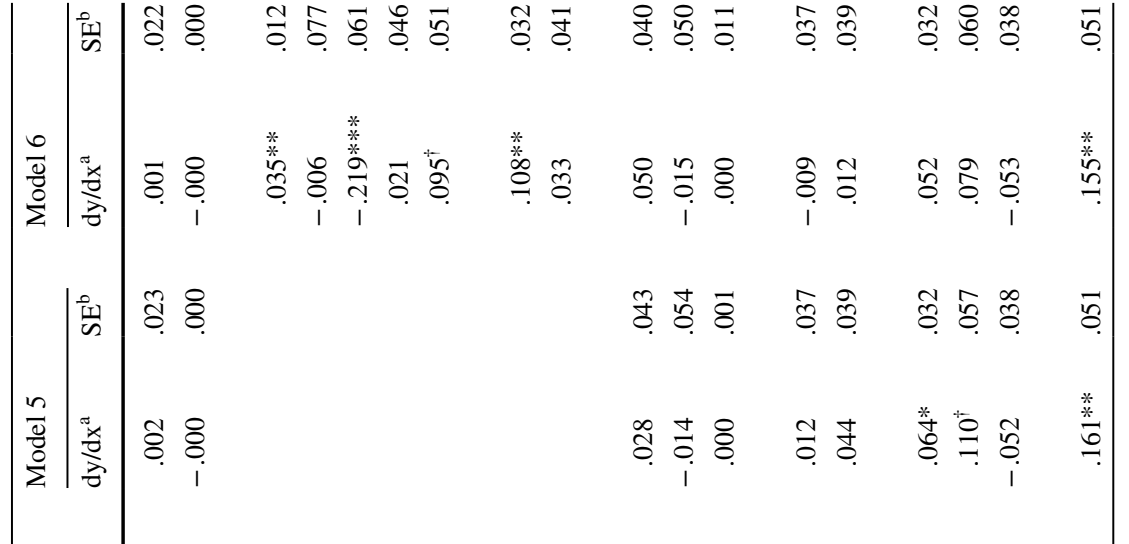

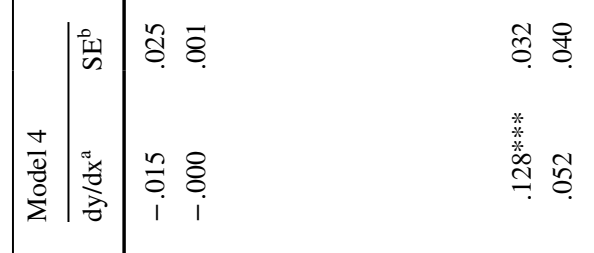

$$
\begin{aligned}
& \text {. }
\end{aligned}
$$$$
\text { 事离 }
$$

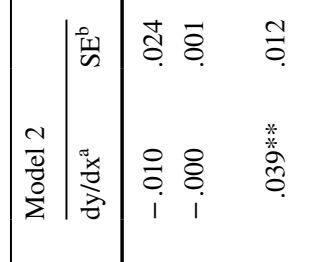

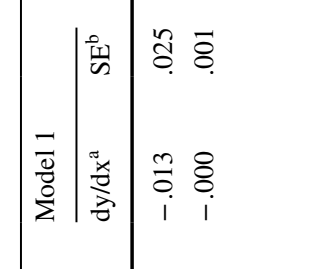




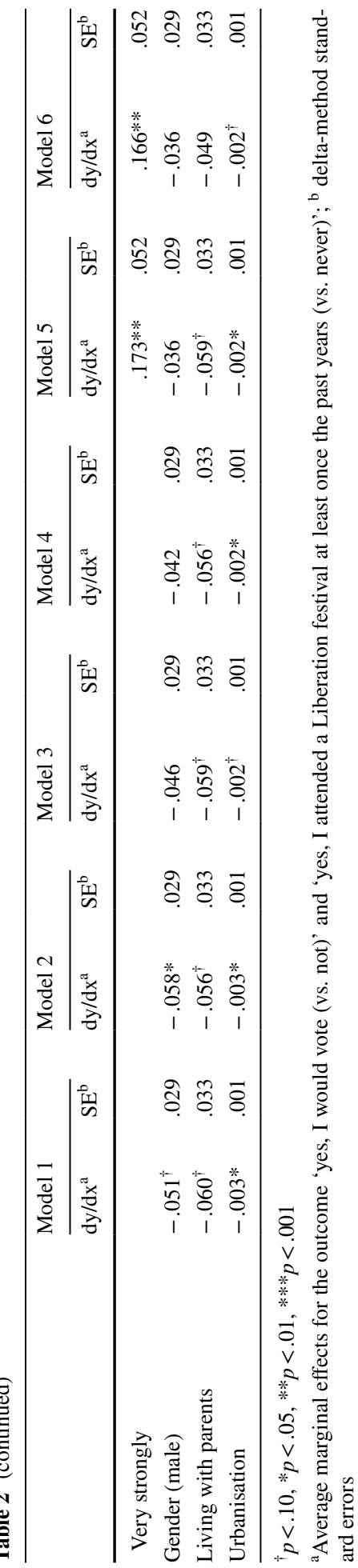


Liberation festival attendance on voting inclination when compared to Model 1: instead of having a $7 \%$ higher chance of voting, youngsters who had visited a Liberation festival over the past years were now shown to be $6 \%$ more likely to vote. However, the change was small, and differences in voting inclinations between young adults who had never versus those who had at least once attended a Liberation festival remained significant. The inclusion of citizenship activities at school or involvement in voluntary organisations led to even smaller changes.

Parental civic communication was found to positively affect both the likelihood of voting (an increased chance of 3\%) and chances of visiting a festival (an increased chance of $4 \%$ ), thereby providing partial support for Hypothesis 2, in which we hypothesised that the positive association between young adults' previous attendance at Liberation festivals and their inclination to vote is partially explained by parental civic communication. We found no evidence for the role of extra-curricular citizenship activities offered at school: not in positively predicting either political or commemorative participation, nor in explaining associations between previous festival attendance and voting intentions (Hypothesis 3 ). Contradicting our initial expectation, young adults who had attended schools organizing democracy-related excursions were $20 \%$ less likely to have visited a Liberation festival. Stepwise analyses showed a similar picture for democracy-related in-school activities, such as debates or mock elections. Furthermore, in line with expectations, young adults who performed voluntary work were, on average, $7 \%$ more likely to vote, and $13 \%$ more likely to attend a Liberation festival, thereby providing partial support for Hypothesis 4.

In Model 5, we examined the extent to which educational track, parental socioeconomic status, reading and museum activities, and ethnic and national identification explain the found association between young adults' previous festival attendance and their voting intentions. A comparison with Model 1 revealed that, although the AME of Liberation festival attendance on voting inclinations in Model 5 was somewhat smaller (i.e. $6 \%$ instead of $7 \%$ ), the adjustment was minor, and the effect was still statistically significant. Young adults who followed a college or university track had a 9 and $14 \%$ higher chance respectively of voting in the next elections than youngsters with a vocational trajectory, yet did not differ in their chances of having visited a Dutch Liberation festival, thereby providing no support for Hypothesis 5a. Hypothesis 5b, on the role of parental socioeconomic status, and Hypothesis 5c, on the role of reading activities, were not supported either, as none of the effects were significant. Young adults who more often visited museums, however, were both more likely to vote (between 5 and $11 \%$, depending on the frequency of activities), and $6 \%$ more likely to visit a Liberation festival, thereby providing partial support for Hypothesis 5d.

National identification was also proven to be an important predictor of both past festival attendance and future voting intentions. Youngsters who identified more strongly with Dutch society had a 10 and $16 \%$ higher chance of voting and having attended a Liberation festival respectively compared to those who did not identify with Dutch society. These findings suggest evidence in support of Hypothesis 6b: The positive association between young adults' attendance at Dutch Liberation festivals and their inclination to vote can be partially explained by their national identification. In Model 5, no effect was found of ethnic identification. Stepwise analyses, however, indicated initially significant, negative effects of ethnic identification on both voting intentions and festival attendance, which disappeared after the addition of national identification. When not controlling for national identification, young adults who identified with a non-Dutch ethnic group were 6 and 8\% less likely to vote and visit a Liberation festival, respectively. These findings thus provide partial support for Hypothesis $6 a$. 
In Model 6, all alternative explanations were included simultaneously. Even though this resulted in a further reduction of the AME of previous Liberation festival attendance on future voting inclination, the effect was still significant: young people who had attended a Liberation festival were 5\% more likely to vote. All in all, our results thus do not provide proof of a spurious relationship between young people's previous Liberation festival attendance and their future voting intentions.

\subsection{Additional Analyses}

To ensure that the found effect of previous Liberation festival attendance on voting intentions did not differ across groups, additional analyses were conducted in which we included interactions with our sociodemographic variables (i.e. educational trajectory, parental socioeconomic status, reading and museum activities, and ethnic and national identification). The results of these analyses, which can be found in Table 4 in the "Appendix", show that the effect of festival attendance on voting intentions was not dependent on any of the sociodemographic characteristics included in this study.

Moreover, to perform a stricter test of the potentially explanatory role of school in the association between Liberation festival attendance and voting intentions, we conducted a school-fixed-effects analysis, which controls for all characteristics of the school. This also resulted in a larger sample $(N=2025)$, since also schools without information on their citizenship activities could be included in the analysis. As Table 5 in the "Appendix" shows, the positive effect of previous Liberation festival attendance on voting intentions remained significant, indicating that the school environment does not explain this association.

\section{Conclusion and Discussion}

To shed more light on the potential of (informal) national commemorations as motivators of young people's political behaviour, this article examined the extent to which 18-yearolds' previous participation in Dutch Liberation festivals is related to their intentions to vote. Using structural equation modelling, we subsequently tested whether this relationship was truly evidence of a motivating effect, or that it was in fact a spurious association. To do so, we considered several alternative explanations of positive associations between young people's commemorative and political participation identified in previous studies as important determinants of young citizens' civic engagement. Our findings, however, show that, even after taking into account the civic home environment, the civic school environment, the out-of-school environment, and numerous sociodemographic factors, the difference in voting chances between young adults who had never versus once or more visited a Liberation festival remains statistically significant (i.e. young adults who have attended a Dutch Liberation festival over the past years are around 5\% more likely to be inclined to vote in the next parliamentary elections), suggesting that there is indeed a motivating effect of this particular type of commemoration on young people's intentions to participate in political activities.

Although systematic empirical research on the consequences of commemorative participation is limited, there have been some studies on the role of remembrance education, including commemorative activities organized in the school context (Cowan and Maitles 2007, 2011). Based on comparisons of students' attitudes and behaviours before and after they studied the Holocaust and visited the Auschwitz-Birkenau Memorial Museum, these 
studies conclude that remembrance education can promote young citizens' civic attitudes and behaviours by developing an understanding and knowledge of broader human rights issues relating to historical and contemporary issues. The current study suggests that the findings from Cowan and Maitles may also apply in a non-educational setting. The present findings furthermore show that Dutch Liberation festivals are a popular form of commemorating amongst youth: almost $60 \%$ has visited one at least once over the last years. Moreover, festival attendance does not depend upon young adults' educational track or their parents' socioeconomic status, suggesting that this type of informal commemoration, which combines musical performances of famous artists with raising awareness of war, freedom, and other core democratic rights and values, is a relatively inclusive form of commemoration attracting a large, heterogeneous segment of the population-at least amongst youth. These findings are in line with earlier studies emphasising the attractiveness of "popular culture' elements amongst young citizens (Van Eijck and Knulst 2005), also in national commemorations (Fricke 2013).

One aspect that does influence one's chances of participating in commemorative activities is ethnic identification: young people who identify themselves with a non-Dutch ethnic group have lower chances of having visited a Liberation festival than young people who do not identify with a non-Dutch ethnic group. The findings furthermore show that this is explained by lower levels of national identification, i.e. they feel less like a member of Dutch society. National identification was found to be an important predictor of both voting intentions and festival attendance amongst all youngsters. These findings suggest that Dutch Liberation festivals might place greater emphasis on the sufferings and heroism of the Dutch rather than 'core democratic values', thereby failing to foster engagement in the event amongst youth who identify less with Dutch society. This is similar to what was found in an earlier study on commemorative participation amongst Dutch citizens with a (non-Western) migration background (Coopmans et al. 2016), and highlights the importance of taking into account both ethnic and national identification when examining inclinations to participate in commemorative activities, also amongst young Dutch people with grand- or great-grandparents born abroad.

The civic home environment also plays a key role in young people's commemorative and political activities. The positive association that is found between Liberation festival attendance and voting intentions is partially due to the more civically engaged home environment. Young adults who more frequently discussed political and social issues with their parents are not only more inclined to vote, but also have higher chances of having visited a Liberation festival. Although youth participating in Liberation festivals appear to be a heterogeneous crowd when it comes to educational and socioeconomic background, they are thus more 'selective' where civic home environment is concerned. These findings not only support previous studies on the vital role of parental communication in youth's civic socialisation processes (Hooghe and Boonen 2015; Jennings et al. 2009; Quintelier 2015b), they also highlight that mnemonic socialisation, or, more specifically, the socialisation of commemorative practices, is not restricted to communication about the historical events that are the topic of these commemorations but instead can comprise a broader range of civic issues. This conclusion is not only a valuable extension of mnemonic socialisation theories, but also has important practical implications for those keen on promoting commemorative participation amongst young people.

In addition to the civic home environment, leisure time activities outside the home environment are also found to play a role in young people's commemorative and political participation. In line with previous research (Marzana et al. 2012; McFarland and Thomas 2006; Quintelier 2008, 2015a), youngsters who are more frequently involved in voluntary 
organisations are not only more likely to vote, but are also more likely to visit Liberation festivals. A similar picture is found for museum activities: young adults who more frequently visit museums have also more often visited Liberation festivals and are more inclined to vote. These findings support earlier studies on this topic (Cowan and Maitles 2011; Savenije and De Bruijn 2017). Moreover, they suggest that cultural resources provide a better explanation for the association between young adults' commemorative and political participation than economic resources (see also Bourdieu 1984; Bourdieu and Passeron 1977), which is in line with the idea that cultural, commemorative, and political activities are all part of a broader civic engagement (Adler and Goggin 2005; Amnå 2012).

The civic school environment, in this study measured as the extra-curricular citizenship activities offered by a school, was not found to influence the association between Liberation festival attendance and voting intentions. Moreover, no effect was found on young adults' political engagement, which seems to contradict previous studies (although, admittedly, the evidence so far has been mixed; Geboers et al. 2013). One explanation for this lack of effect is that we have concentrated on the citizenship activities offered, not considering the student's actual participation in the organised activities. Even though voluntary extra-curricular citizenship activities at school have been found to have a more positive impact on young people's citizenship than obligatory activities (Geboers et al. 2013), this approach ignores within-school differences between students actively and less actively participating in the organised activities. An alternative explanation is that other forms of citizenship education, such as the pedagogical climate or curriculum in school, are more effective in impacting adolescents' future citizenship behaviours. School fixed effects models, however, indicated that the found association between commemorative and political participation could not be explained by the school. This is in line with a recent study by Dijkstra and colleagues (Dijkstra et al. 2015), in which it was concluded that citizenship outcomes are better explained by factors at the student level than at the school level. An interesting avenue for future research would therefore be to zoom in on the civic engagement of and civic talks with peers, both inside and outside school, as they are an important source of influence during adolescence (Brechwald and Prinstein 2011).

To be able to draw firmer conclusions regarding an actual motivating effect of young people's participation in informal commemorations on their political participation, longitudinal research is needed to more reliably test the causality of the relationship between the various activities. Moreover, a more comprehensive picture of the complete civic and political socialisation process is needed, including a wider variety of political attitudes and behaviours (see for instance Oser 2017). Ideally, we would follow youngsters during different developmental phases of their civic socialisation, creating a dataset with extensive information on changes in their political, social, and cultural activities, and including not only voting intentions but also actual voter turnout (even though Hainmueller et al. (2015), for instance, quite convincingly demonstrate the close link between hypothetical and actual voting choices). This would also enable us to examine more dynamic processes such as the influence of changes in social environments (e.g. switching classes, schools, and going off to college), or interactions between different social environments at different points in time (e.g. the changing role of parents versus peers), as well as the underlying mechanisms that explain how participation in commemorative activities can lead to more political participation in later life.

In one of the national surveys conducted by the National Committee 4 and 5 May, for instance, over $70 \%$ of the respondents indicated to use Dutch Remembrance Day and Liberation Day to reflect on issues relating to (un)freedom, human rights, and democracy (Verhue et al. 2017). Changes in awareness of and attitude on democratic rights and 
values as a potential mediator could therefore be an interesting starting point. Another interesting follow-up of the current research would be to track youngsters more closely during their Liberation festival visits, to determine factors contributing to or disturbing the politically motivating role of Dutch Liberation festivals. A mobile application could, for instance, be used to register their activities and interactions with other festival visitors. This would enable us to find out more about the concrete reasons for a potential impact of attending Liberation festivals on young people's political behaviours. What happens during this event that makes people more interested or ready to participate? Is it the veterans' stories, is it concrete political statements, or something else? Does everybody who attends such an event also attend the politically relevant parts of it? A recent study by De Regt and Van der Lippe (2017) suggests otherwise. Answers to these questions would allow for more in-depth analysis and are an interesting avenue for future research.

All in all, however, the present findings provide tentative evidence of a positive influence of previous participation in Dutch Liberation festivals on young adults' voting intentions, thereby supporting Sapiro (2004) in her claim that the commemoration of a national past should be considered a relevant aspect of political socialisation. Even though the effect is relatively small, the combination of popular culture elements, shared moments, and references to past and present issues relating to war and freedom used in Dutch Liberation festivals to emphasise the importance of core democratic values such as freedom and tolerance seems to motivate young visitors to contribute to the continuance of the democratic system, at least when it comes to voting. Combined with the fact that the Liberation festivals are a popular activity amongst young adults from various socioeconomic backgrounds, and can therefore be considered a relatively inclusive activity, this study shows that informal commemorations, such as the Dutch Liberation festivals examined, have the potential to promote political participation amongst all young people equally. At the same time, Liberation festivals are less often attended by youth identifying with a non-Dutch ethnic background-which is explained by lower levels of national identification - thereby risking reinforcing gaps in political engagement between youth with and without a migration background.

Acknowledgements Earlier versions of this article were presented at the "CILS4EU 2015 conference" in Stockholm, the "Migration and Social Stratification seminar" in Utrecht, and the "111th ASA Annual Meeting" in Seattle. The author thanks participants in those sessions for their helpful comments and is especially grateful for the insightful suggestions of Duane Alwin, Eva Jaspers, Tanja van der Lippe, Marcel Lubbers, Miles Hewstone, Sabrina De Regt, Sara Geven, and Bas Hofstra on previous drafts of this paper.

Funding CILS4EU was funded by the NORFACE ERA NET Plus Migration in Europe-programme. CILSNL is part of the research programme Investeringen Middelgroot MaGW with Project Number 48011-013, which is (partly) financed by the Netherlands Organisation for Scientific Research (NWO).

Open Access This article is distributed under the terms of the Creative Commons Attribution 4.0 International License (http://creativecommons.org/licenses/by/4.0/), which permits unrestricted use, distribution, and reproduction in any medium, provided you give appropriate credit to the original author(s) and the source, provide a link to the Creative Commons license, and indicate if changes were made.

\section{Appendix}

See Tables 3, 4 and 5 . 
Table 3 Datasets used for variable construction

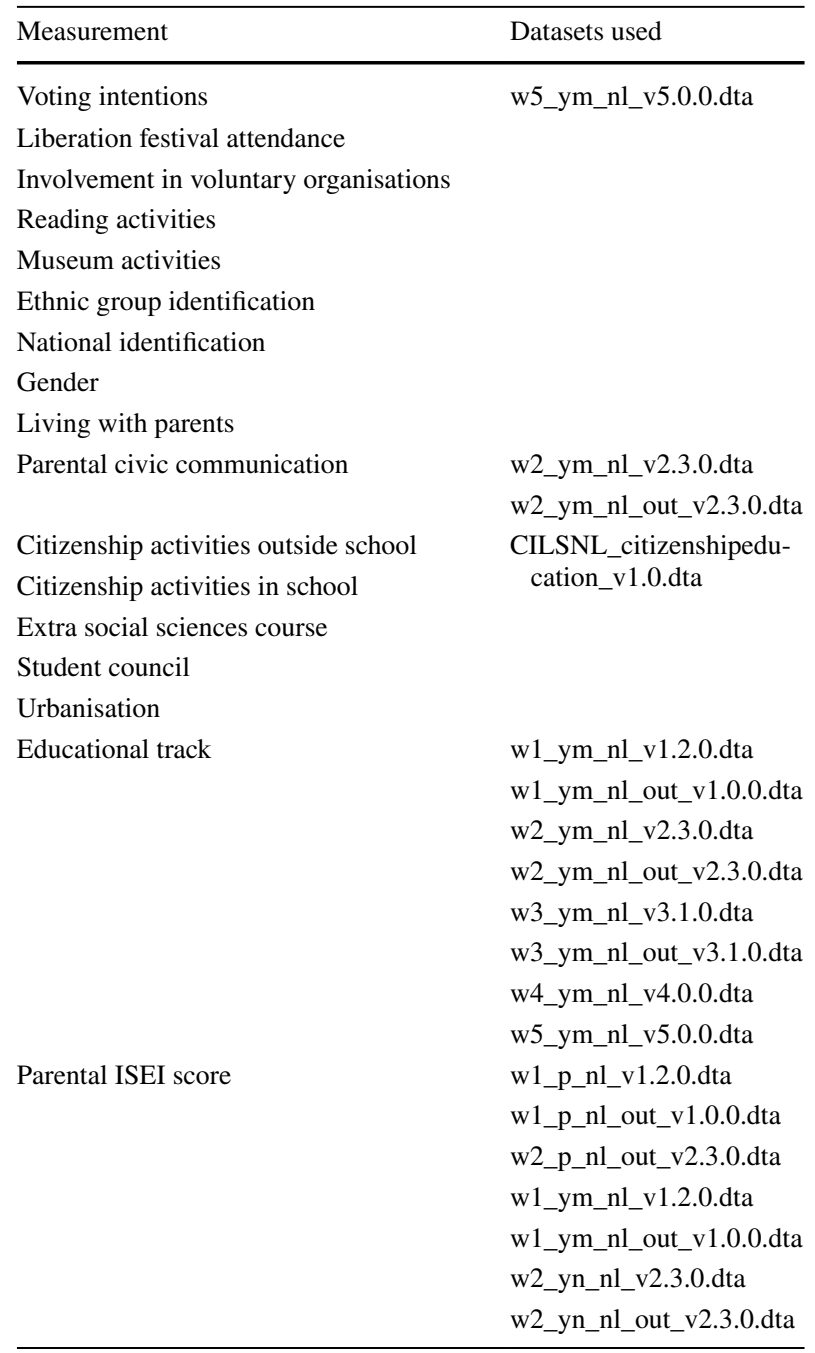




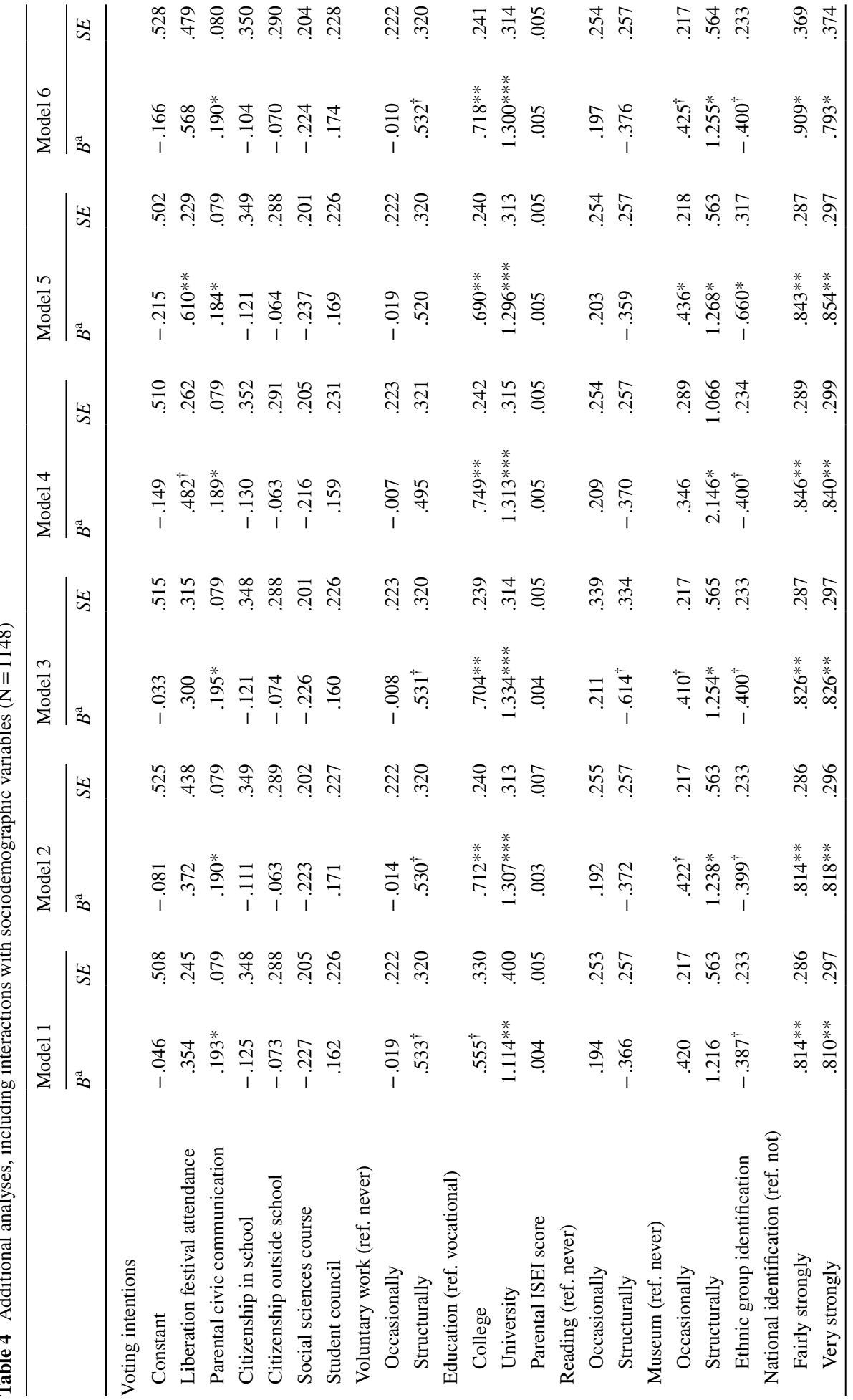




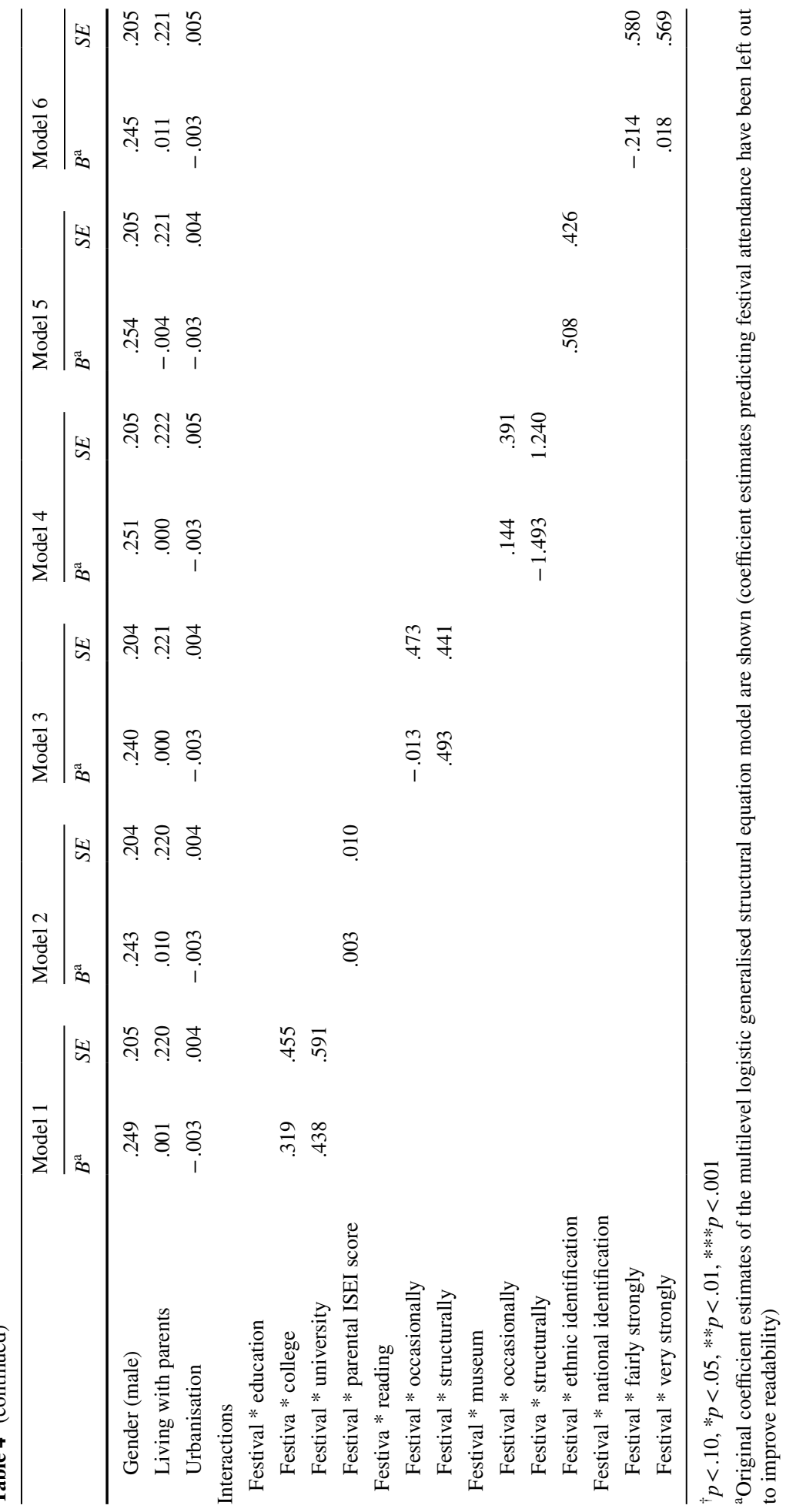


Table 5 Additional analyses, school fixed effects model predicting voting intentions $(\mathrm{N}=2025)$

\begin{tabular}{|c|c|c|}
\hline & $\mathrm{B}^{\mathrm{a}}$ & SE \\
\hline Liberation festival attendance & $.444^{* *}$ & .152 \\
\hline Parental civic communication & $.233 * * *$ & .056 \\
\hline \multicolumn{3}{|l|}{ Voluntary work (ref. never) } \\
\hline Occasionally & .200 & .168 \\
\hline Structurally & .194 & .208 \\
\hline \multicolumn{3}{|l|}{ Education (ref. vocational) } \\
\hline College & $.725 * *$ & .248 \\
\hline University & .472 & .383 \\
\hline Parental ISEI score & $.007^{\dagger}$ & .004 \\
\hline \multicolumn{3}{|l|}{ Reading (ref. never) } \\
\hline Occasionally & .285 & .181 \\
\hline Structurally & -.071 & .188 \\
\hline \multicolumn{3}{|l|}{ Museum (ref. never) } \\
\hline Occasionally & $.350 *$ & .160 \\
\hline Structurally & $1.001^{*}$ & .387 \\
\hline Ethnic group identification & -.258 & .181 \\
\hline \multicolumn{3}{|l|}{ National identification (ref. not) } \\
\hline Fairly strongly & $.436^{*}$ & .216 \\
\hline Very strongly & $.757 * *$ & .227 \\
\hline Gender (male) & $.319 *$ & .149 \\
\hline Living with parents & .161 & .160 \\
\hline
\end{tabular}

${ }^{\dagger} p<.10, * p<.05, * * p<.01, * * * p<.001$

${ }^{a}$ Original coefficient estimates of the conditional fixed-effects logistic regression are shown

\section{References}

Adler, R. P., \& Goggin, J. (2005). What do we mean by 'civic engagement'? Journal of Transformative Education, 3, 236-253.

Ajzen, I. (1991). The theory of planned behavior. Orgnizational Behavior and Human Decision Processes, 50, 179-211.

Amnå, E. (2012). How is civic engagement developed over time? Emerging answers from a multidisciplinary field. Journal of Adolescence, 35, 611-627.

Beck, P. A., \& Jennings, M. K. (1982). Pathways to participation. The American Political Science Review, 76, 94-108.

Bourdieu, P. (1984). Distinction: A social critique of the judgement of taste. Cambridge, MA: Harvard University Press.

Bourdieu, P., \& Passeron, J.-C. (1977). Reproduction in education, society and culture. London: Sage Publications.

Bovens, M., \& Wille, A. (2010). The education gap in participation and its political consequences. Acta Politica, 45, 393-422.

Brechwald, W. A., \& Prinstein, M. J. (2011). Beyond homophily: A decade of advances in understanding peer influence processes. Journal of Research on Adolescence, 21, 166-179.

Cassel, C. A. (1999). Voluntary associations, churches, and social participation theories of turnout. Social Science Quarterly, 80, 504-517.

Cicognani, E., Zani, B., Fournier, B., Gavray, C., \& Born, M. (2012). Gender differences in youths' political engagement and participation. The role of parents and of adolescents' social and civic participation. Journal of Adolescence, 35, 561-576.

CILS4EU. (2016). Children of immigrants longitudinal survey in four European countries. Technical report. Wave 1-2010/2011, v1.2.0. Mannheim: Mannheim University. 
Collins, R. (2004). Interaction ritual chains. Princeton: Princeton University Press.

Coopmans, M. (2016). CILSNL citizenship education-v1.0. DANS.

Coopmans, M., Jaspers, E., \& Lubbers, M. (2016). National day participation among immigrants in the Netherlands: The role of familiarity with commemorating and celebrating. Journal of Ethnic and Migration Studies, 42, 1925-1940.

Coopmans, M., Lubbers, M., \& Meuleman, R. (2015). To whom do national days matter? A comparison of national belonging across generations and ethnic groups in the Netherlands. Ethnic and Racial Studies, 38, 2037-2054.

Coppock, A., \& Green, D. P. (2016). Is voting habit forming? New evidence from experiments and regression discontinuities. American Journal of Political Science, 60, 1044-1062.

Cowan, P., Kenig, N., \& Mycock, A. (2014). The complexities of citizenship education and remembrance. London: CiCe.

Cowan, P., \& Maitles, H. (2007). Does addressing prejudice and discrimination through Holocaust education produce better citizens? Educational Review, 59, 115-130.

Cowan, P., \& Maitles, H. (2011). 'We saw humanity close up'. What is gained by school students from Scotland visiting Auschwitz? Journal of Curriculum Studies, 43, 163-184.

De Graaf, N. D., De Graaf, P. M., \& Kraaykamp, G. (2000). Parental cultural capital and educational attainment in the Netherlands: A refinement of the cultural capital perspective. Sociology of Education, 73, 92.

De Regt, S., \& Van der Lippe, T. (2017). Does participation in national commemorations increase cohesion in society? A study of Dutch liberation festivals. Studies in Ethnicity and Nationalism, 17, 281-289.

De Rooij, E. (2012). Patterns of immigrant political participation: Explaining differences in types of political participation between immigrants and the majority population in Western Europe. European Sociological Review, 28, 455-481.

Dijkstra, A. B., Geijsel, F., Ledoux, G., van der Veen, I., \& ten Dam, G. (2015). Effects of school quality, school citizenship policy, and student body composition on the acquisition of citizenship competences in the final year of primary education. School Effectiveness and School Improvement, 26, 524-553.

Durkheim, E. (1912-1995). The elementary forms of religious life. New York: Free Press.

Elgenius, G. (2011). The politics of recognition: Symbols, nation building and rival nationalisms. Nations and Nationalism, 17, 396-418.

Eurydice. (2012). Citizenship education in Europe. Brussels: Education, Audiovisual and Culture Executive Agency.

Fieldhouse, E., Tranmer, M., \& Russell, A. (2007). Something about young people or something about elections? Electoral participation of young people in Europe: Evidence from a multilevel analysis of the European social survey. European Journal of Political Research, 46, 797-822.

Fox, J. E. (2014). National holiday commemorations. The view from below. In R. Tsang \& E. T. Woods (Eds.), The cultural politics of nationalism and nation-building. Ritual and performance in the forging of nations (pp. 38-53). New York: Routledge.

Fricke, C. (2013). Protocol, politics and popular culture: The independence jubilee in Gabon. Nations and Nationalism, 19, 238-256.

Ganzeboom, H. B. G., De Graaf, P. M., \& Treiman, D. J. (1992). A standard international socio-economic index of occupational status. Social Science Research, 21, 1-56.

Geboers, E., Geijsel, F., Admiraal, W., \& ten Dam, G. (2013). Review of the effects of citizenship education. Educational Research Review, 9, 158-173.

Glass, J., Bengtson, V. L., \& Dunham, C. C. (1986). Attitude similarity in three-generation families: Socialization, status inheritance, or reciprocal influence? American Sociological Review, 51, 685.

Hainmueller, J., Hangartner, D., \& Yamamoto, T. (2015). Validating vignette and conjoint survey experiments against real-world behavior. Proceedings of the National Academy of Sciences of the United States of America, 112, 2395-2400.

Haskins, E. V. (2015). Popular memories: Commemoration, participatory culture, and democratic citizenship. Columbia: University of South Carolina Press.

Hooghe, M., \& Boonen, J. (2015). The intergenerational transmission of voting intentions in a multiparty setting: An analysis of voting intentions and political discussion among 15-year-old adolescents and their parents in Belgium. Youth \& Society, 47, 125-147.

Hoskins, B., Janmaat, J. G., \& Villalba, E. (2012). Learning citizenship through social participation outside and inside school: an international, multilevel study of young people's learning of citizenship. British Educational Research Journal, 38, 419-446.

Humphries, M., Muller, C., \& Schiller, K. S. (2013). The political socialization of adolescent children of immigrants. Social Science Quarterly, 94, 1261-1282. 
Jaspers, E., Lubbers, M., de Vries, J., \& De Vries, J. (2008). Parents, children and the distance between them: Long term socialization effects in the Netherlands. Journal of Comparative Family Studies, 39, 39-58.

Jaspers, E., \& van Tubergen, F. (2014). Children of immigrants longitudinal survey in the Netherlands (CILSNL)—Wave 4. Full version v4.0.0. DANS.

Jaspers, E., \& van Tubergen, F. (2015). Children of immigrants longitudinal survey in the Netherlands (CILSNL)—Wave 5. Full version v5.0.0. DANS.

Jennings, M. K., Stoker, L., \& Bowers, J. (2009). Politics across generations: Family transmission reexamined. The Journal of Politics, 71, 782-799.

Kalter, F., Heath, A. F., Hewstone, M., Jonsson, J. O., Kalmijn, M., Kogan, I., \& Van Tubergen, F. (2016a). Children of immigrants longitudinal survey in four European countries (CILS4EU)—Full version. Data file for on site use. GESIS Data Archive, Cologne, ZA5353 Data file Version 1.2.0.

Kalter, F., Heath, A. F., Hewstone, M., Jonsson, J. O., Kalmijn, M., Kogan, I., \& Van Tubergen, F. (2016b). Children of immigrants longitudinal survey in four European countries (CILS4EU)—Full version. Data file for on site use. GESIS Data Archive, Cologne, ZA5353 Data file Version 2.3.0.

Kalter, F., Heath, A. F., Hewstone, M., Jonsson, J. O., Kalmijn, M., Kogan, I., \& Van Tubergen, F. (2016c). Children of immigrants longitudinal survey in four European countries (CILS4EU)—Full version. Data file for on site use. GESIS Data Archive, Cologne, ZA5353 Data file Version 3.1.0.

Keating, A., \& Janmaat, J. G. (2016). Education through citizenship at school: Do school activities have a lasting impact on youth political engagement? Parliamentary Affairs, 69, 409-429.

Liu, J. H., Goldstein-Hawes, R., Hilton, D., Huang, L.-L., Gastardo-Conaco, C., Dresler-Hawke, E., et al. (2005). Social representations of events and people in world history across 12 cultures. Journal of Cross-Cultural Psychology, 36, 171-191.

Liu, J. H., \& Hilton, D. J. (2005). How the past weighs on the present: Social representations of history and their role in identity politics. British Journal of Social Psychology, 44, 537-556.

Lubbers, M., \& Meuleman, R. (2016). Participation in national celebrations and commemorations: The role of socialization and nationalism in the Dutch context. Social Science Research, 55, 111-121.

Manning, N., \& Edwards, K. (2014). Does civic education for young people increase political participation? A systematic review. Educational Review, 66, 22-45.

Marzana, D., Marta, E., \& Pozzi, M. (2012). Social action in young adults: Voluntary and political engagement. Journal of Adolescence, 35, 497-507.

McCrone, D., \& McPherson, G. (2009). Introduction. In D. McCrone \& G. McPherson (Eds.), National days. Constructing and mobilising national identity (pp. 1-10). Basingstoke: Palgrave.

McFarland, D. A., \& Thomas, R. J. (2006). Bowling young: How youth voluntary associations Influence adult political participation. American Sociological Review, 71, 401-425.

Messina, A. M. (2007). The logics and politics of post-world war II migration to western Europe. Cambridge: Cambridge University Press.

Mood, C. (2010). Logistic regression: Why we cannot do what we think we can do, and what we can do about it. European Sociological Review, 26, 67-82.

NOS. (2017). Vrouwen houden van Jesse Klaver, ouderen van de PvdA. Retrieved March 18, 2017, from http://nos.nl/artikel/2163765-vrouwen-houden-van-jesse-klaver-ouderen-van-de-pvda.html.

Olsen, M. E. (1972). Social participation and voting turnout: A multivariate analysis. American Sociological Review, 37, 317-333.

Oser, J. (2017). Assessing how participators combine acts in their 'political tool kits': A person-centered measurement approach for analyzing citizen participation. Social Indicators Research, 133, 235-258.

Parsons, T., \& Bales, R. F. (1956). Family socialization and interaction processes. London: Routledge and Kegan Paul Ltd.

Plutzer, E. (2002). Becoming a habitual voter: Inertia, resources, and growth in young adulthood. The American Political Science Review, 96, 41-56.

Putnam, R. D. (2000). Bowling alone: The collapse and revival of American community. New York: Simon $\&$ Schuster.

Quintelier, E. (2008). Who is politically active: The athlete, the scout member or the environmental activist?: Young people, voluntary engagement and political participation. Acta Sociologica, 51, 355-370.

Quintelier, E. (2009). The political participation of immigrant youth in Belgium. Journal of Ethnic and Migration Studies, 35, 919-937.

Quintelier, E. (2015a). Engaging adolescents in politics: The longitudinal effect of political socialization agents. Youth \& Society, 47, 51-69.

Quintelier, E. (2015b). Intergenerational transmission of political participation intention. Acta Politica, 50, 279-296. 
Renan, E. (1882-1990). What is a nation? In H. K. Bhabha (Ed.), Nation and narration (pp. 8-22). London: Routledge.

Russo, S., \& Stattin, H. (2017). Stability and change in youths' political interest. Social Indicators Research, 132, 643-658.

Sanders, D., Fisher, S. D., Heath, A., \& Sobolewska, M. (2014). The democratic engagement of Britain's ethnic minorities. Ethnic and Racial Studies, 37, 120-139.

Sapiro, V. (2004). Not your parents' political socialization: Introduction for a new generation. Annual Review of Political Science, 7, 1-23.

Savenije, G. M., \& De Bruijn, P. (2017). Historical empathy in a museum: uniting contextualisation and emotional engagement. International Journal of Heritage Studies, 23, 832-845.

Schmid, C. (2012). The value 'social responsibility' as a motivating factor for adolescents' readiness to participate in different types of political actions, and its socialization in parent and peer contexts. Journal of Adolescence, 35, 533-547.

Schwartz, B. (2015). Commemoration. In J. D. Wright (Ed.), International encyclopedia of the social and behavioral sciences (2nd ed., Vol. 4, pp. 235-242). Amsterdam: Elsevier.

Sherrod, L. R., Flanagan, C., \& Youniss, J. (2002). Dimensions of citizenship and opportunities for youth development: The what, why, when, where, and who of citizenship development. Applied Developmental Science, 6, 264-272.

Sloam, J. (2014). New voice, less equal: The civic and political engagement of young people in the United States and Europe. Comparative Political Studies, 47, 663-688.

StataCorp. (2017). Stata statistical software: Release 15. College Station, TX: StataCorp LLC.

Statistics Netherlands. (2016). Statline table: Bevolking; hoogst behaald onderwijsniveau; geslacht, leeftijd en herkomst. Retrieved February 13, 2017, from http://statline.cbs.n1/Statweb/publicatio $\mathrm{n} / ? \mathrm{DM}=\mathrm{SLNL} \& \mathrm{PA}=82275 \mathrm{NED} \& \mathrm{D} 1=0 \& \mathrm{D} 2=0 \& \mathrm{D} 3=2 \& \mathrm{D} 4=0 \& \mathrm{D} 5=0,2-4,8-10,12-14 \& \mathrm{D} 6=1 \& \mathrm{HD}$ $\mathrm{R}=\mathrm{T}, \mathrm{G} 1, \mathrm{G} 3, \mathrm{G} 5 \& \mathrm{STB}=\mathrm{G} 2, \mathrm{G} 4 \& \mathrm{VW}=\mathrm{T}$.

Ten Dam, G., Geijsel, F., Reumerman, R., \& Ledoux, G. (2011). Citizenship competences: The development of a measurement instrument. European Journal of Education, 46, 354-372.

Ten Dam, G., \& Volman, M. (2007). Educating for adulthood or for citizenship: Social competence as an educational goal. European Journal of Education, 42, 281-298.

Van Eijck, K., \& Knulst, W. (2005). No more need for snobbism: Highbrow cultural participation in a taste democracy. European Sociological Review, 21, 513-528.

Van Ingen, E., \& Van der Meer, T. (2016). Schools or pools of democracy? A longitudinal test of the relation between civic participation and political socialization. Political Behavior, 38, 83-103.

Van Nieuwenhuyse, K., \& Wils, K. (2012). Remembrance education between history teaching and citizenship education. Citizenship Teaching \& Learning, 7, 157-171.

Verba, S., \& Nie, N. H. (1972). Participation in America: Political democracy and social equality. New York: Harper \& Row.

Verba, S., Schlozman, K. L., \& Brady, H. E. (1995). Voice and equality. Civic voluntarism in American politics. Cambridge, MA: Harvard University Press.

Verhue, D., Koenen, B., \& Tilanus, A. (2017). Nationaal Vrijheidsonderzoek 2017. Beleving, houding en draagvlak ten aanzien van 4 en 5 mei. Amsterdam: Kantar Public \& Nationaal Comité 4 en 5 mei.

White, S., Nevitte, N., Blais, A., Gidengil, E., \& Fournier, P. (2008). The political resocialization of immigrants: Resistance or lifelong learning? Political Research Quarterly, 61, 268-281. 